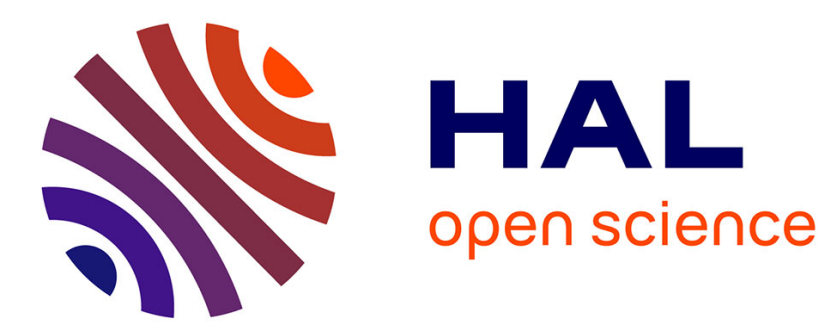

\title{
Vertical distribution of aerosols in dust storms during the Arctic winter
}

\author{
Pavla Dagsson-Waldhauserova, Jean-Baptiste Renard, Haraldur Olafsson, \\ Damien Vignelles, Gwenaël Berthet, Nicolas Verdier, Vincent Duverger
}

\section{- To cite this version:}

Pavla Dagsson-Waldhauserova, Jean-Baptiste Renard, Haraldur Olafsson, Damien Vignelles, Gwenaël Berthet, et al.. Vertical distribution of aerosols in dust storms during the Arctic winter. Scientific Reports, 2019, 9 (1), 11 p. 10.1038/s41598-019-51764-y . insu-02483471

\section{HAL Id: insu-02483471 https://hal-insu.archives-ouvertes.fr/insu-02483471}

Submitted on 18 Feb 2020

HAL is a multi-disciplinary open access archive for the deposit and dissemination of scientific research documents, whether they are published or not. The documents may come from teaching and research institutions in France or abroad, or from public or private research centers.
L'archive ouverte pluridisciplinaire HAL, est destinée au dépôt et à la diffusion de documents scientifiques de niveau recherche, publiés ou non, émanant des établissements d'enseignement et de recherche français ou étrangers, des laboratoires publics ou privés. 


\title{
Vertical distribution of aerosols in dust storms during the Arctic winter
}

\author{
Pavla Dagsson-Waldhauserova $\mathbb{1}^{1,2^{*}}$, Jean-Baptiste Renard ${ }^{3}$, Haraldur Olafsson ${ }^{4,5}$, \\ Damien Vignelles ${ }^{3}$, Gwenaël Berthet ${ }^{3}$, Nicolas Verdier ${ }^{6}$ \& Vincent Duverger ${ }^{3}$
}

High Latitude Dust (HLD) contributes 5\% to the global dust budget, but HLD measurements are sparse. Dust observations from Iceland provide dust aerosol distributions during the Arctic winter for the first time, profiling dust storms as well as clean air conditions. Five winter dust storms were captured during harsh conditions. Mean number concentrations during the non-dust flights were $<5$ particles $\mathrm{cm}^{-3}$ for the particles $0.2-100 \mu \mathrm{m}$ in diameter and $>40$ particles $\mathrm{cm}^{-3}$ during dust storms. A moderate dust storm with $>250$ particles $\mathrm{cm}^{-3}\left(2 \mathrm{~km}\right.$ altitude) was captured on $10^{\text {th }}$ January 2016 as a result of sediments suspended from glacial outburst flood Skaftahlaup in 2015 . Similar concentrations were reported previously in the Saharan air layer. Detected particle sizes were up to $20 \mu \mathrm{m}$ close to the surface, up to $10 \mu \mathrm{m}$ at $900 \mathrm{~m}$ altitude, up to $5 \mu \mathrm{m}$ at $5 \mathrm{~km}$ altitude, and submicron at altitudes $>6 \mathrm{~km}$. Dust sources in the Arctic are active during the winter and produce large amounts of particulate matter dispersed over long distances and high altitudes. HLD contributes to Arctic air pollution and has the potential to influence ice nucleation in mixed-phase clouds and Arctic amplification.

The Arctic surface atmosphere has undergone radical changes in past decades resulting in at least two times larger warming $\left(\sim 1.5^{\circ} \mathrm{C}\right)$ than the global mean temperature change. Such Arctic warming, often referred to as Arctic amplification, is attributed to greenhouse gas feedback while short-lived aerosols act as important forcing agents as well ${ }^{1-4}$. The most radiation absorbing aerosols known in the Arctic atmosphere are black carbon and dark-coloured dust, but they have been also identified as strong light absorbing impurities when deposited on snow or ice ${ }^{1,5-11}$. Although the direct radiative forcing of aerosols in the Arctic atmosphere is estimated to be larger than indirect radiative forcing via snow feedback, early snow cover removal can result in comparatively larger climate effects ${ }^{12}$. The seasonality of high aerosol loadings in the Arctic is typically bimodal, with one major peak in late winter/spring and the secondary peak in autumn ${ }^{3,13}$.

The origin of absorbing particles is mostly attributed to long-range transport from outside of the Arctic. However, within the Arctic region there are large areas where the terrain serves as sources of dust that impact high latitudes ${ }^{14,15}$. We refer to these as High Latitude Dust sources (HLD). The first estimates are that all HLD sources cover $>500,000 \mathrm{~km}^{2}$ and contribute to at least $5 \%$ of the global dust budget ${ }^{14}$. Iceland is the largest Arctic as well as European desert, comprised of volcanic and glacio-volcanic sediments, with high dust event frequency $(>135$ dust days annually) and year round occurrence ${ }^{14,16-19}$. Icelandic volcanic dust can be transported distances over $1000 \mathrm{~km}$ and it can affect large Arctic glaciated and sea areas due to its deposition on snow, ice and sea ice $e^{9,17,20-25}$. Direct aerosol measurements in Iceland have shown high Particulate Matter (PM) mass and number concentrations during dust storms in situ ${ }^{22,26-28}$ and on board of the aircraft ${ }^{29}$. Snow-dust storms (when dust is mixed with snow during a dust storm or deposited on snow) and some of the most extreme wind erosion events recorded on Earth have been observed and measured in Iceland, the most active HLD source in the Arctic ${ }^{14,17,28,30,31}$.

Measurement of the vertical distribution of aerosols is crucial for understanding the physical properties of tropospheric Arctic aerosols. However, scientific studies of airborne measurements of aerosol distribution in the Arctic are rare. Reported direct aerosol concentration measurements in vertical atmospheric profiles in the Arctic are limited to spring/summer season and low altitude of atmospheric profile (altitude $\sim 2 \mathrm{~km}$ in Laakso et al. ${ }^{32},<3$ $\mathrm{km}$ in Bates et al. ${ }^{33},<1 \mathrm{~km}$ in Moroni et al. ${ }^{34}$, and $\sim 1 \mathrm{~km}$ in Ferrero et al. $\left.{ }^{35}\right)$. Winter direct measurements of Arctic aerosol profiles for the whole troposphere column in addition to the presence of the polar vortex are scarce due to

${ }^{1}$ Agricultural University of Iceland; Faculty of Environmental Sciences, Hvanneyri, Borgarnes, IS 311 , Iceland. ${ }^{2}$ Czech University of Life Sciences Prague, Faculty of Environmental Sciences, Department of Ecology, Prague, 16000 , Czech Republic. ${ }^{3}$ LPC2E-CNRS, 3 A avenue de la recherche scientifique, 45071, Orléans cedex 2, France. ${ }^{4}$ University of Iceland, Department of Physical Sciences, Reykjavík, IS 101, Iceland. ${ }^{5}$ Icelandic Meteorological Office, Reykjavik, Iceland. ${ }^{6}$ Centre National d'Etudes Spatiales, 18 avenue Edouard Belin, 31055, Toulouse cedex, France. *email: pavla@Ibhi.is 


\begin{tabular}{|l|l|l|l|l|l|}
\hline Date & $\begin{array}{l}\text { Time of } \\
\text { measurements } \mathbf{( T U )}\end{array}$ & Launch location & $\begin{array}{l}\text { Altitude } \\
\text { range }(\mathbf{k m})\end{array}$ & Tropopause $(\mathbf{k m})$ & $\begin{array}{l}\text { Dust } \\
\text { event }\end{array}$ \\
\hline 7 Nov. 2013 & $11: 23-12: 01$ & $64.127^{\circ} \mathrm{N}, 21.911^{\circ} \mathrm{W}$ & $0.1-11.2$ & 8.0 & Yes \\
\hline 28 Jan. 2015 & $10: 43-12: 48$ & $64.346^{\circ} \mathrm{N}, 21.436^{\circ} \mathrm{W}$ & $2.8-32.6$ & Not measured & No \\
\hline 9 Jan. 2016 & $15: 08-16: 12$ & $63.856^{\circ} \mathrm{N}, 20.229^{\circ} \mathrm{W}$ & $0.1-14.6$ & 10.5 & Yes \\
\hline 10 Jan. 2016 & $12: 11-13: 44$ & $64.329^{\circ} \mathrm{N}, 21.652^{\circ} \mathrm{W}$ & $0.1-26.5$ & 11.5 & Yes \\
\hline 12 Jan. 2016 & $11: 33-12: 47$ & $64.337^{\circ} \mathrm{N}, 21.614^{\circ} \mathrm{W}$ & $0.1-18.9$ & 9.0 & Yes \\
\hline 13 Jan. 2016 & $10: 34-11: 40$ & $64.337^{\circ} \mathrm{N}, 21.615^{\circ} \mathrm{W}$ & $0.1-14.6$ & 8.0 & Yes* $^{*}$ \\
\hline
\end{tabular}

Table 1. Conditions of measurements. Date, time, location, altitude range of the flights, altitude of the tropopause, and presence of dust event of conducted flights in 2013-2016. *Not detected by LOAC.

operational and weather issues ${ }^{36}$. Vertical distribution of tropospheric aerosols during dark winter months can be retrieved, however, from satellite instruments ${ }^{37,38}$. Most of the direct vertical aerosol studies are focused on fine mode particles with a diameter $<500 \mathrm{~nm}$, but coarse particles including giant particles such as with a diameter $>30 \mu \mathrm{m}$ are capable of long range transport as well ${ }^{39-43}$. Aerosol studies on long-range transport of coarse and giant particles in the Arctic are generally missing.

The main objective of this study was to provide the first atmospheric vertical profiles of aerosol concentrations from balloon-borne measurements in the lower Arctic, Iceland, in winter. The purpose was to identify: (i) Icelandic dust storms and focus on understanding winter dust storms in the Arctic; (ii) number and mass concentrations with the size distributions of Icelandic dust aerosols; (iii) the nature of particles in the Icelandic lower atmosphere; and (iv) the presence of dust particles during and after snow and rain. The observations presented here provide, for the first time, a quantitative picture of dust aerosol distributions during the Arctic winter.

\section{Results}

Vertical profile measurements to detect liquid and solid atmospheric aerosols using Light Optical Aerosol Counter (LOAC) and related meteorological parameters were conducted in south-western Iceland in 2013-2016 (for details see section Methods). Table 1 shows the description of the flights and Supplementary Fig. S1 the locations of balloon launches as well as desert and dust sources in Iceland. Different types of atmospheric aerosols were identified at several altitudes during all six flights (Fig. 1). Four out of six vertical profiles confirmed Icelandic volcanic dust, although it occurred in freezing winter or during the precipitation season: $7^{\text {th }}$ November $2013,9^{\text {th }}$ January $2016,10^{\text {th }}$ January 2016 , and $12^{\text {th }}$ January 2016 . Clean atmospheric conditions with a presence of liquid and sulphuric aerosols in the stratosphere were captured on $28^{\text {th }}$ January 2015 and $13^{\text {th }}$ January $2016^{44}$. In the free troposphere, mean number concentrations during the non-dust flights were $<5$ particles $\mathrm{cm}^{-3}$ for particles $>0.2 \mu \mathrm{m}$ in diameter, while mean number concentrations during the flights with dust presence increased $>40$ particles $\mathrm{cm}^{-3}$.

The concentrations of submicron particles vary between the flights, generally showing higher concentrations during dust presence than for clean condition for this Arctic region depending on the size range (Fig. 2). The shape of size distribution as shown, for example, at $3 \mathrm{~km}$ altitude for all the flights is not the only indicator of dust presence. The typology must be considered as in Fig. 1. Large particles $>50 \mu \mathrm{m}$ at such an altitude during the dust event on $12^{\text {th }}$ January 2016 refer for example to ice particles in cloud (Figs 1 and 2). The presence of dust was unambiguously detected (please see the section Methods - LOAC for detailed description) for the $9^{\text {th }}, 10^{\text {th }}$ and $12^{\text {th }}$ January 2016 flights while traces of dust mixed with other aerosols were likely present during the fight on $7^{\text {th }}$ November 2013.

The best captured dust layer was recorded by Light Optical Aerosol counter (LOAC) during the flight on $10^{\text {th }}$ January 2016 (Fig. 1). The speciation index (described in Methods) inside a dust layer clearly determined dust typology (Fig. 3, left image) while the speciation index cannot be exactly determined for upper layer at $7 \mathrm{~km}$ where various types of aerosols were detected.

\section{Dust Events and Clean Background Conditions}

Dust Event $1-7^{\text {th }}$ November 2013. On 6-7 $7^{\text {th }}$ November 2013, there were strong easterly winds in south-western Iceland, associated with a low-pressure system to the southwest of Iceland. Dust events occurred frequently in south-western Iceland from $1^{\text {st }}$ November 2013 prior to the balloon launch on $7^{\text {th }}$ November 2013. Surface $\mathrm{PM}_{10}$ concentrations in Reykjavik for the days prior to the LOAC flight were about fourfold higher than the long term average $\left(\mathrm{PM}_{10}>100 \mu \mathrm{gm}^{-3}\right)$. The main source was the Hagavatn dust source $\left(64^{\circ} 27^{\prime} 40.0^{\prime \prime} \mathrm{N}\right.$, $20^{\circ} 19^{\prime} 15.5^{\prime \prime} \mathrm{W}$, Supplementary Fig. S1) ${ }^{17}$ about $70 \mathrm{~km}$ from the place of the measurements and balloon launch, Reykjavik. Snow showers and rain mixed with snow occurred frequently during the day. This caused abrupt changes in the surface $\mathrm{PM}_{10}$ concentrations in Reykjavik ${ }^{45}$ with frequent peaks above $100 \mu \mathrm{gm}^{-3}$ and drops to $<10 \mu \mathrm{gm}^{-3}$. Dust was visually observed although frequent snow-rain showers occurred.

Figure 1 shows the vertical profile of the flight up to $11 \mathrm{~km}$ with the typology of captured particles. The atmosphere at an altitude of $<1 \mathrm{~km}$ was abundant in liquid droplets, while a residual layer of suspended dust was detected at an altitude of about $900 \mathrm{~m}$. The dust particles in this layer were mostly submicronic, but several particles up to $10 \mu \mathrm{m}$ were also recorded. LOAC passed through cloud at 4 to $5 \mathrm{~km}$ altitude as shown by the presence of large ice particles (up to $50 \mu \mathrm{m}$ ) in typology as well as captured in the relative humidity profile. Traces of dust were also detected at an altitude of about $6.5 \mathrm{~km}$. Carbonaceous particles were mainly identified during the flight at altitudes $>8 \mathrm{~km}$. This aerosol profile confirmed the occurrence of a small dust event with wet deposition removal 

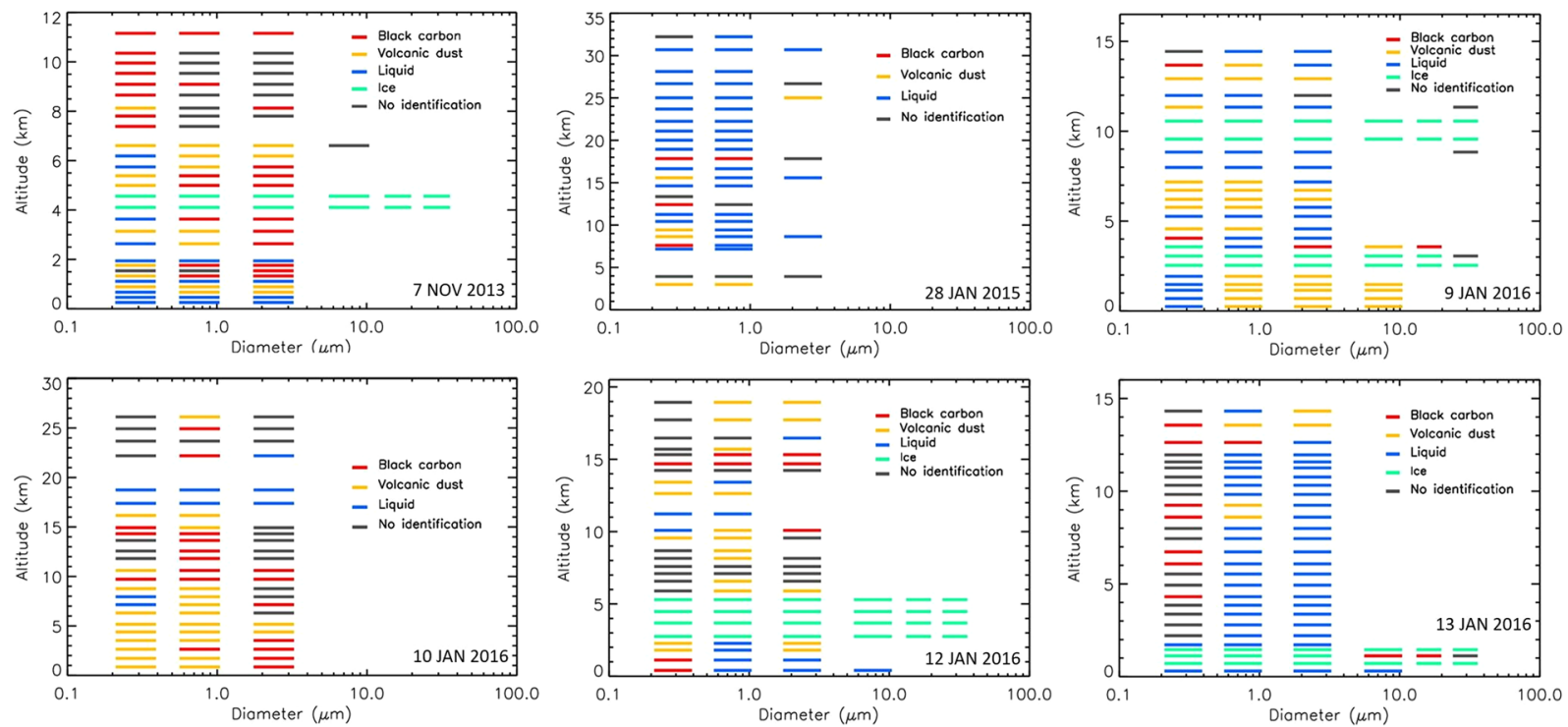

Figure 1. Vertical particle size distributions of the typologies for the flights on 7 th November 2013, $28^{\text {th }}$ January $2015,9^{\text {th }}$ January $2016,10^{\text {th }}$ January $2016,12^{\text {th }}$ January 2016 , and $13^{\text {th }}$ January 2016 . Liquid refers to transparent droplets (fog, cloud, liquid marine droplets with salt).

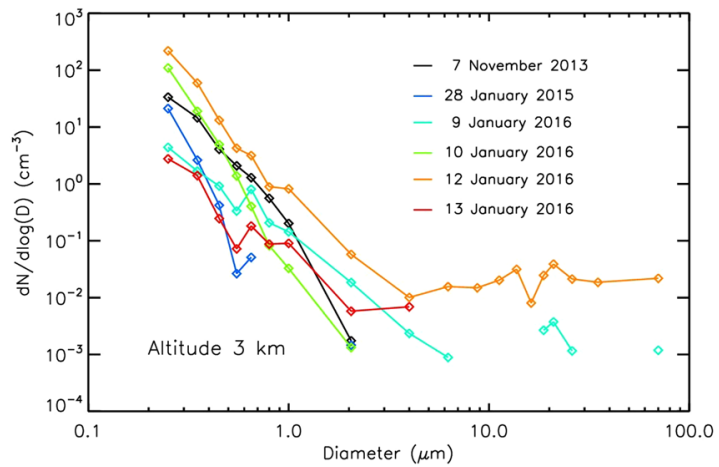

Figure 2. Size distribution for all the flights at an altitude of $3 \mathrm{~km}$.
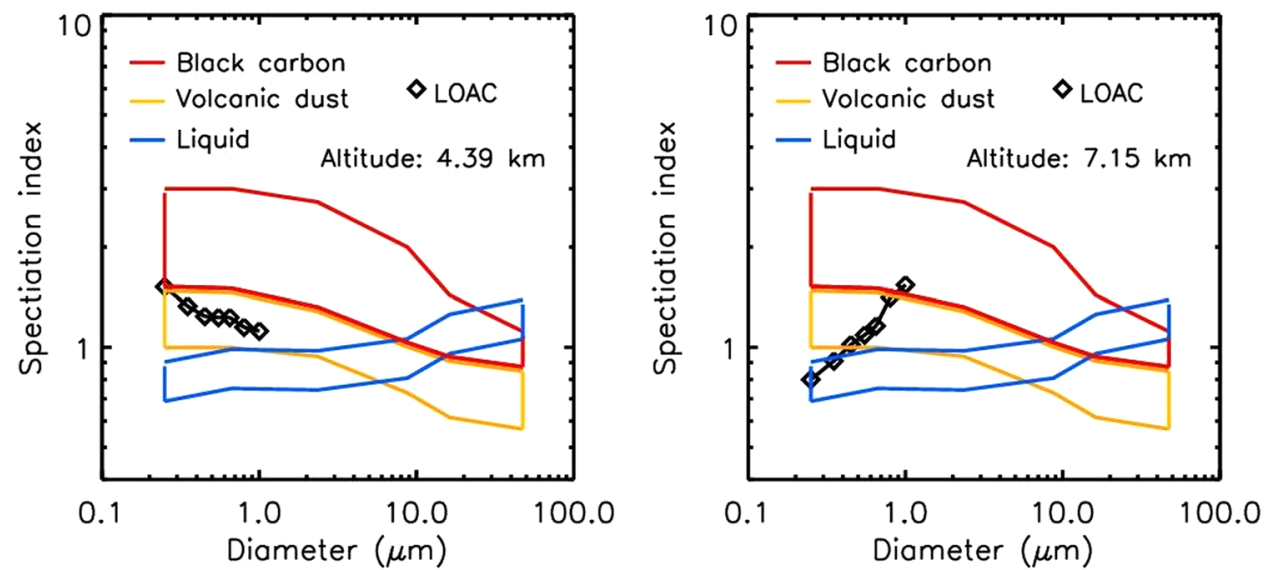

Figure 3. LOAC speciation index for $10^{\text {th }}$ January 2016 flight. Left: Inside a volcanic dust layer; right: Above the dust layer, where no identification of the particles can be done, probably because of the presence of various types of aerosols.

of dust particles at an altitude $<900 \mathrm{~m}$. The total number concentration for Event 1 was 40 particles $\mathrm{cm}^{-3}$, while $\mathrm{PM}_{10}$ mass concentration was in the $5-10 \mu \mathrm{gm}^{-3}$ range. Mean daily surface $\mathrm{PM}_{10}$ concentrations measured by the Environment Agency of Iceland (EAI) ${ }^{45}$ in Reykjavik were $24 \mu \mathrm{gm}^{-3}$. 


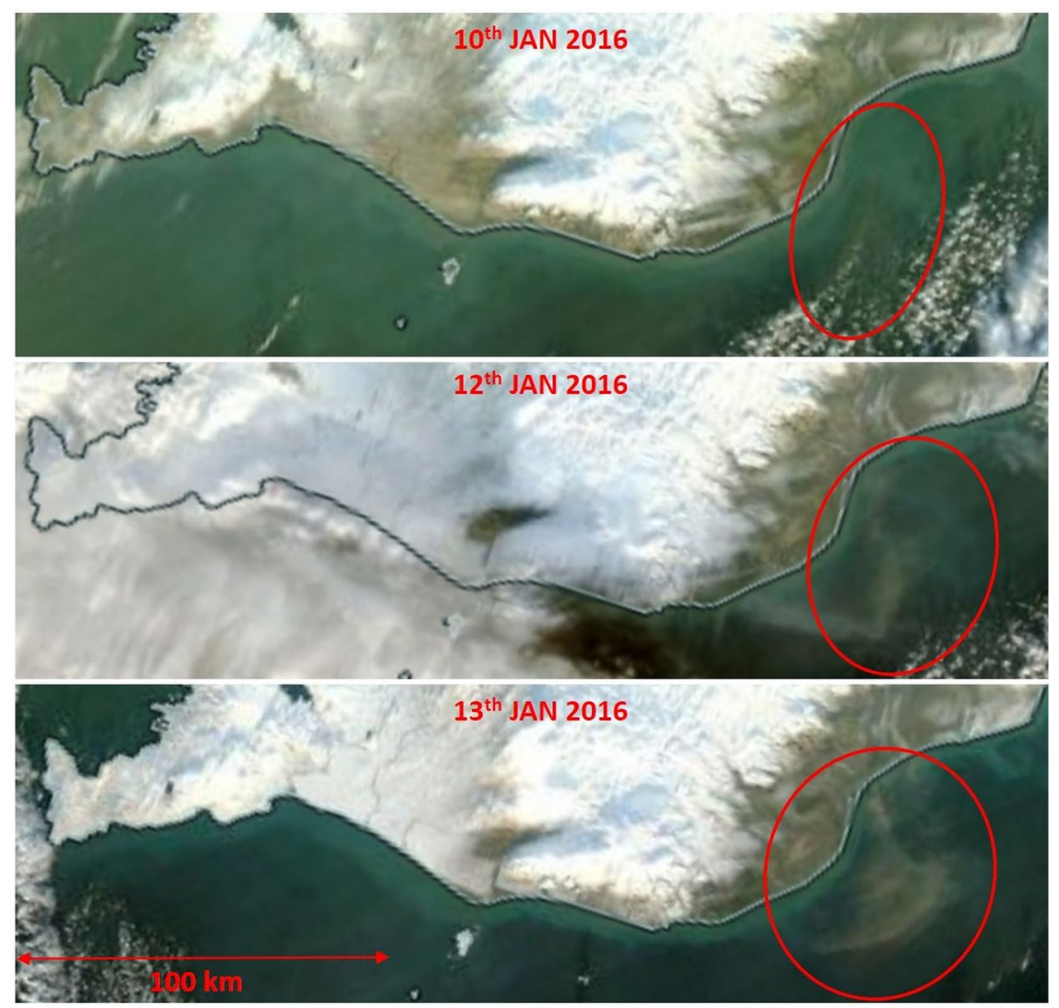

Figure 4. MODIS Aqua true-colour satellite images of southern Iceland from $10^{\text {th }}, 12^{\text {th }}$ and $13^{\text {th }}$ January 2016 with no cloud obstruction of the dust plumes (marked red). Active dust sources are in italic. Image courtesy of the NASA Worldview (https://worldview.earthdata.nasa.gov/).

Flight on $28^{\text {th }}$ January 2015-clean air conditions. A meso- to synoptic scale trough was over south-western Iceland, embedded in a north-easterly and larger scale low-level flow. A balloon was launched from Reykjavik in a temperature of about $0^{\circ} \mathrm{C}$ and winds generally from NW to $\mathrm{N}$, but only $5-10 \mathrm{~ms}^{-1}$ throughout the troposphere. The total number concentration for non-polluted air was of about $1-5$ particles $\mathrm{cm}^{-3}$ and the $\mathrm{PM}_{10}$ mass concentration was of about 2-5 $\mu \mathrm{gm}^{-3}$. Low surface $\mathrm{PM}_{10}$ concentrations (daily mean of $14 \mu \mathrm{gm}^{-3}$ ) did not exceed $25 \mu \mathrm{gm}^{-3}$ at the aerosol monitoring station in Reykjavik.

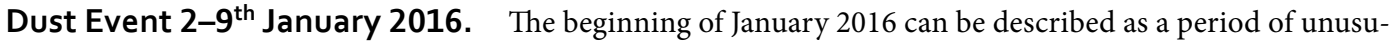
ally cold conditions when snow cover exceeded $90 \%$ of the country and a strong polar vortex developed above Iceland ${ }^{46}$. Surface temperatures were below $0^{\circ} \mathrm{C}$ and dropped to $-70^{\circ} \mathrm{C}$ at altitudes above $10 \mathrm{~km}$.

On $9^{\text {th }}$ January 2016, there was a deep low moving to the east and south of Iceland and there were strong low-level winds from the east, northeast over Iceland. Most of the dust sources were covered with snow, but recently exposed sediments after subglacial eruption 'Skaftárhlaup' in Southern Iceland were frequently suspended as captured by MODIS satellite (Fig. 4). Visible dust plumes over the ocean were mostly transported south- and southwest-wards of Iceland during strong north-easterly winds. The balloon was launched from the area close to the village of Hella in southern Iceland (Supplementary Fig. S1). The only operating instrument in Reykjavik $^{45}$ (about $250 \mathrm{~km}$ northwest from the source area) captured increased PM concentrations ( $\mathrm{PM}_{10}$ up to $150{\mu \mathrm{gm}^{-3}}$ and $\mathrm{PM}_{2.5}$ up to $110 \mu \mathrm{gm}^{-3}$ ) on $9^{\text {th }}\left(\right.$ mean $\mathrm{PM}_{10}=19 \mu \mathrm{gm}^{-3}$ with $\max >40 \mu \mathrm{gm}^{-3}$ ) and $10^{\text {th }}$ January 2016. Figure 1 show the vertical profile on 9 th January 2016 up to $14 \mathrm{~km}$ and typology of captured particles. Two dust layers were detected by LOAC, one from the ground to an altitude of $2 \mathrm{~km}$, and another between 6 and $7 \mathrm{~km}$. Clouds were crossed at altitudes of 3-4 km, and cirrus at altitudes of 9-11 km. The highest concentrations of 70 $\mathrm{cm}^{-3}$ were detected at an altitude of $6.5 \mathrm{~km}$, giving a relatively low $\mathrm{PM}_{10}$ mass concentration of about $5 \mu \mathrm{gm}^{-3}$, mainly showing the presence of submicron particles. An additional thin aerosol layer can be seen in the lower stratosphere at about $13 \mathrm{~km}$. This could be related to the descent of solid particles from the polar vortex.

Dust Event 3-10 th $^{\text {th }}$ anuary 2016. Dust event 3, on $10^{\text {th }}$ January 2016, was captured well during the flight, showing the highest dust rates in the troposphere from all the flights (Fig. 1). The balloon was launched from Hvalfjördur Bay in south-western Iceland (Supplementary Fig. S1). A trough formed over western Iceland and the wind profile (Supplementary Fig. S2) is on the eastern edge of the trough, featuring southerly and south-easterly winds of $5 \mathrm{~ms}^{-1}$ in the lower and middle troposphere. These winds transported dust particles westwards from the source at Skaftarhlaup, as shown in Fig. 4. Wind profiles obtained from the LOAC flight show surface winds arriving from the directions where increased $\mathrm{PM}_{10}$ concentrations were measured (Reykjavik, mean surface $\mathrm{PM}_{10}=67$ 
$\mu \mathrm{gm}^{-3}$ with 30 - $\min \max >150 \mu \mathrm{gm}^{-3}$ ). There was a wind direction change (linked with wind velocity increase) at altitudes between 1-2 km showing winds arriving from the area of suspended jökulhlaup sediments.

The speciation index mainly indicated dust particles in the whole troposphere for particles $<5 \mu \mathrm{m}$ (Figs 1,3 ). The larger particles were attributed to "black carbon" typology at altitudes $<5 \mathrm{~km}$. These aerosols were either carbonaceous particles or (aggregates of) volcanic dust particles that are highly porous and strongly optically absorbing. For altitudes above $5 \mathrm{~km}$ in the troposphere, the typology results are more scattered although optically absorbing particles seem to dominate. The highest concentrations were at an altitude of $2 \mathrm{~km}$ with about 250 particles $\mathrm{cm}^{-3}$ while the mass concentration was in the $10-15 \mu \mathrm{gm}^{-3}$ range, showing a lack of large particles.

Flights during the Dust Event 4-12-13 ${ }^{\text {th }}$ January 2016. On 12 January 2016, there were lows traveling to the south and southeast of Iceland giving strong north-easterly low-level winds over Iceland itself. Satellite images in Fig. 4 show dust events in southern Iceland on $12^{\text {th }}$ and $13^{\text {th }}$ January 2016. Surface concentrations in Reykjavik were, however, low (mean daily $\mathrm{PM}_{10}<13 \mu \mathrm{gm}^{-3}$ ) due to the winds arriving from different directions than the active dust sources (Supplementary Figs S1, S2). LOAC was launched in Hvalfjordur, about $200 \mathrm{~km}$ northwest from the dust source, on $12^{\text {th }}$ January 2016 and it did capture a small amount of dust in the troposphere. The mean number concentration detected by LOAC in the free troposphere was about 20 particles $\mathrm{cm}^{-3}$, while total mass concentration was $2-5 \mu^{-3} \mathrm{gm}^{-3}$. Wind profiles on $12^{\text {th }}$ January in Supplementary Fig. S2 show a low-level north-easterly jet of about $15 \mathrm{~ms}^{-1}$, turning to weaker north-westerly winds at middle tropospheric levels. On $13^{\text {th }}$ January 2016, the low-level NE winds were down to $8-10 \mathrm{~ms}^{-1}$, with westerly 5-10 $\mathrm{ms}^{-1}$ at middle-tropospheric levels. Surface wind speeds were considerable higher on $12^{\text {th }}$ January than $13^{\text {th }}$ January 2016 . No dust was detected on the $13^{\text {th }}$ January flight, with the presence of only about 5 particles $\mathrm{cm}^{-3}$. Daily mean $\mathrm{PM}_{10}$ concentrations from the station in Reykjavik were $10-13 \mu \mathrm{gm}^{-3}$.

\section{Discussion}

Six successful winter balloon launches were conducted in Iceland in 2013-2016, despite the harsh outside conditions with winds at the highest level possible for such a launch. Atmospheric profiles (up to $32 \mathrm{~km}$ ) of aerosol distributions were measured for both clean Arctic air and air heavily polluted by natural volcanic dust from the local Arctic (Icelandic) deserts and fresh sediments from Skaftárhlaup frequently suspended after a subglacial eruption in September 2015. The vertical profiles with dust concentrations at different altitudes do not show evident dust layers as detected previously with LOAC in Saharan dust plumes ${ }^{42}$. Saharan dust layers are unambiguously characterized by the presence of a coarse mode of particles of at least several micrometres ${ }^{39-43}$. Measured dust layers of local, glacially reworked, volcanic materials in Iceland are often comprised of submicron sized particles, resulting in low mass concentrations ${ }^{26,28}$. Such volcanic dust particles can be precisely identified by combining particle counting and optical typology measurement methods, as obtained with LOAC. High proportions of submicron particles have been observed during previous in situ measurements of Icelandic dust storms ${ }^{26,28}$. The highest number concentrations of dust particles $(0.3-10 \mu \mathrm{m})$ were in the size range $0.3-0.337 \mu \mathrm{m}$ in a dust storm in 2013 . High $\mathrm{PM}_{1}$ concentrations were also measured during two dust storms in 2015 , where the $\mathrm{PM}_{1} / \mathrm{PM}_{10}$ mass ratios ranged from $0.34-0.63$. Moreover, submicron/supermicron ratios of 0.5 were calculated from particle number concentrations measured during the flight of aircraft inside Icelandic dust storm in $2017^{47}$. Such high ratios are usually reported in polluted urban areas in Europe or Asia, rather than during natural dust air pollution.

All winter dust events presented here were either captured by the satellite or reported from the surface $\mathrm{PM}_{10}$ measurements at the Reykjavik EAI station (Fig. 4). The long-term frequency of dust events in the southern part of Iceland showed that about half of reported dust events in 1949-2011 occurred during winter or sub-zero temperatures ${ }^{16}$. Vignelles et al. ${ }^{48}$ observed dust plumes from desert surfaces in northeast Iceland in January 2015. Winter dust storm occurrence in Arctic areas such as Iceland is important because of the interaction of dust and cryosphere. Snow Dust Storm phenomena occur in Iceland while albedo reduction and melting of the glaciers are caused due to light absorbing impurity, dark volcanic dust, in Iceland ${ }^{10,28,49}$ and in the Arctic ${ }^{9,24}$.

Quantifying the aerosol distributions in high atmospheric profiles gives an overview of air quality for clean background Arctic conditions as well as polluted air conditions. The number concentrations during the cleanest conditions were $<5$ particles $\mathrm{cm}^{-3}$ in the $0.2-100 \mu \mathrm{m}$ size range. It is difficult to provide comparisons with our measurements in clean background conditions due to the diversity of instruments and particle size ranges for atmospheric profile measurements reported in the literature. Kupiszewski et al. ${ }^{50}$ reported median concentrations of particles with diameter $\mathrm{D}>0.3 \mu \mathrm{m}$ of about 1 particle $\mathrm{cm}^{-3}$ within $1 \mathrm{~km}$ a.g.l. in the high Arctic. Concentrations of $\mathrm{D}_{0.5-1}$ particles ranged from $1-12 \mathrm{~cm}^{-3}$ in coastal Norway ${ }^{51}$. The Arctic aerosol concentration of submicron particles $\left(\mathrm{D}_{0.3-0.8}\right)$ is generally very low, about $1 \mathrm{~cm}^{-3}$ within $1 \mathrm{~km}$ a.g.l., but it can increase by several factors, sometimes by as much as an order of magnitude, at certain heights within the free troposphere ${ }^{52}$. Median monthly $\mathrm{D}_{0.2-0.5}$ concentrations range between about $1-50 \mathrm{~cm}^{-3}$ in the Canadian Arctic and about 5-70 $\mathrm{cm}^{-3}$ in Svalbard, Norway (Mt. Zeppelin) ${ }^{13}$. Background surface concentrations of $\mathrm{D}_{0.26-1.2}$ was $15-38 \mathrm{~cm}^{-3}$ and $\mathrm{D}_{1.2-32}$ was about $0.01-0.3 \mathrm{~cm}^{-3}$ in Svalbard ${ }^{35}$. Concentrations of $\mathrm{D}_{0.25-32}$ were $0.03-0.2 \mathrm{~cm}^{-3}$ during two flights in Svalbard ${ }^{34}$. Increased ground concentrations of $\mathrm{D}_{0.5-20}$ were up to 10 particles $\mathrm{cm}^{-3}$ in Svalbard in April 2011 due to long range transport of Icelandic dust ${ }^{24,34}$. This shows that there is a large diversity in aerosol number concentrations in the Arctic region and our measurements are in good agreement with most of them.

Number concentrations during dusty conditions ranged from $40-250$ particles $\mathrm{cm}^{-3}$ in the $0.2-100 \mu \mathrm{m}$ size range. Concentrations $>200$ particles $\mathrm{cm}^{-3}$ are typical for Saharan dust outbreaks ${ }^{42,53}$. A winter dust storm was measured in Iceland on $25^{\text {th }}$ February 2007, when a Passive Cavity Aerosol Spectrometer Probe (optical counter for particles of $0.1-3 \mu \mathrm{m}$ diameter) was on board the aircraft ${ }^{29}$. About 100-300 particles $\mathrm{cm}^{-3}$ were measured at 400 and $700 \mathrm{~m}$ altitudes inside the dust plume while 10-50 particles $\mathrm{cm}^{-3}$ were measured at an altitude of $1900 \mathrm{~m}$. Large particles $\sim 20 \mu \mathrm{m}$ were collected inside Icelandic dust storm at $320 \mathrm{~m}$ altitude in $2017^{47}$. This shows that dust events cause considerable air pollution as well as influence ice nucleation in mixed-phase clouds in the $\operatorname{Arctic}^{47}$. 


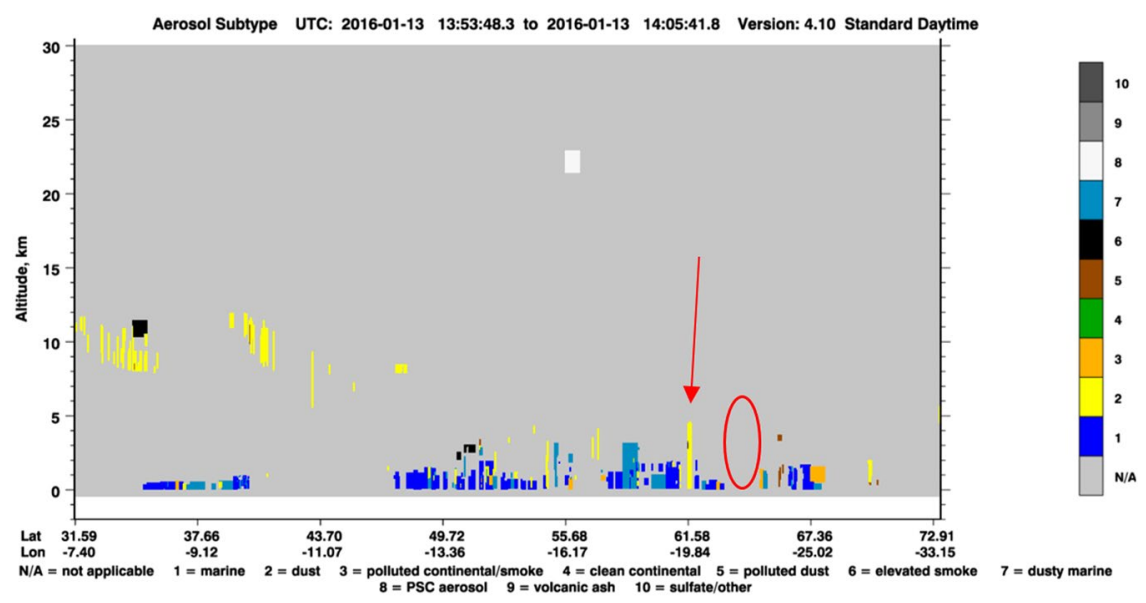

Figure 5. CALIPSO cross sections of $532 \mathrm{~nm}$ total attenuated backscatter and the vertical feature mask for the overpass of Iceland on $13^{\text {th }}$ January 2016. LOAC flight marked with red circle. The relationship between the dust column marked with red arrow and the dust plume captured in Fig. 4 is questionable (image from courtesy of the NASA/CALIPSO system, https://www-calipso.larc.nasa.gov/).

Surface $\mathrm{PM}_{10}$ concentrations during dust events in Reykjavik were about six times higher than non-dusty conditions with 30 -min $\mathrm{PM}_{10}$ peaks $>100 \mu \mathrm{gm}^{-3}$ on $7^{\text {th }}$ November 2013 and $10^{\text {th }}$ January 2016 . On $9^{\text {th }}$ January 2016, twice as high $\mathrm{PM}_{10}$ concentrations than non-dusty conditions were reported. Clean air with daily $\mathrm{PM}_{10}$ mean concentrations of about $10-13 \mu \mathrm{gm}^{-3}$ were measured in Reykjavík on $12-13^{\text {th }}$ January 2016 , but satellite images captured well-developed dust storms in southern Iceland (Fig. 4). The reason for such low concentrations was the wind direction at the measurement site, which changed to northerly and north-westerly winds instead of easterly and south-easterly winds from the active dust sources.

We examined aerosol profiles obtained by the Cloud-Aerosol Lidar and Infrared Pathfinder Satellite Observations (CALIPSO) for the dust events. It was, however, only the launch on $13^{\text {th }}$ January 2016 from all the LOAC flights when the satellite was passing over the exact location of the measurements. The aerosol profiles from the other days are related to the ocean areas outside Iceland. On $7^{\text {th }}$ November 2013, CALIPSO detected marine and dusty marine aerosols at $<1.5 \mathrm{~km}$ altitude, dust in three layers (at about $3 \mathrm{~km}, 5-6 \mathrm{~km}$ and $8-9 \mathrm{~km}$ ) and aerosols attributed to 'elevated smoke' at about $8 \mathrm{~km}$ above the sea about $200 \mathrm{~km}$ south of Iceland. This is in agreement with measurements provided by LOAC which identified: (i) marine aerosols and hydrated dust particles at $<1 \mathrm{~km}$ altitude; (ii) a thin dust layer at about $6 \mathrm{~km}$; and (iii) carbonaceous particles $>8 \mathrm{~km}$. On $28^{\text {th }}$ January 2015 , CALIPSO captured marine aerosols at $<500 \mathrm{~m}$ and a clean profile up to $22 \mathrm{~km}$ altitude over the sea south of Iceland (distance about $150 \mathrm{~km}$ ). Many aerosol types at several altitudes were detected by CALIPSO west of Iceland on $9^{\text {th }}$ January 2016. Aerosols attributed to "polluted dust" and"elevated smoke" were detected at altitudes of 3-4 km and 5-7 km, while dust was at $4-5 \mathrm{~km}$, around $7 \mathrm{~km}$, and 10-11 km (250 km west of Iceland). LOAC measured dust aerosols $<2 \mathrm{~km}, 6-7 \mathrm{~km}$, and at about $13 \mathrm{~km}$. The aerosol signatures in the higher altitudes were comparable to what LOAC captured.

On $10^{\text {th }}$ January 2016, the early morning CALIPSO profile above Iceland showed the presence of marine and marine dusty aerosols at $<1.5 \mathrm{~km}$, "elevated smoke" at $2-3 \mathrm{~km}$, and dust layer at 9-11 km south-easterly of Iceland. Polar Stratospheric Clouds (PSC) were shown at 17-18 km. The afternoon passage was over NE Iceland and related the aerosols to "polluted continental or smoke" origin at altitude $<2 \mathrm{~km}$. A mixture of dust and polluted dust particles was shown at $6-8 \mathrm{~km}$. PSC were at $20-23 \mathrm{~km}$. The speciation index of aerosols detected by LOAC also classified the particles as black carbon at altitudes $<5 \mathrm{~km}$ for particles $>5 \mu \mathrm{m}$. The fine particles were, however, dust. LOAC was flying downwind through the dust plume spotted on the satellite indicating why both datasets are in good agreement. Both instruments have shown the presence of dust particles in higher altitudes up to $10 \mathrm{~km}$.

The CALIPSO passage was too far from Iceland on $12^{\text {th }}$ January 2016 , while it passed over near the location of the LOAC flight on $13^{\text {th }}$ January 2016 at about the same time of the launch. CALIPSO observations showed a clean profile with no aerosol detected when passing over the location of the LOAC flight and further south and southeast (Fig. 5). It suddenly detected an aerosol signature attributed to dust particle from the ground up to $5 \mathrm{~km}$ south of Iceland at about $62 \mathrm{~N} 20 \mathrm{~W}(100 \mathrm{~km}$ of the coast). A profile of about $4 \mathrm{~km}$ from the ground with a dusty marine signature was detected further south and east. The relationship between the CALIPSO observation and the dust plume captured by satellite (Fig. 4) is questionable. It provides a possible explanation of why LOAC did not measure many particles during this particular flight, despite the fact that a dust storm was occurring about $200 \mathrm{~km}$ from the balloon launch. Although CALIPSO may be underestimating optical depths for Saharan dust ${ }^{54}$, it seems to detect well dark volcanic Icelandic dust over sea areas as captured by LOAC. The vertical aerosol measurements in the Arctic from LOAC as well as from CALIPSO have shown that dust can be found at high altitudes, such as up to several $\mathrm{km}$. Dust from the sources located above $60^{\circ} \mathrm{N}$ was found to reach altitudes up to $8 \mathrm{~km}$ in winter emphasizing that Icelandic dust is able to reach the upper Greenland ice sheet ${ }^{15}$. 
It is known from Saharan vertical dust measurements that dust events aged over $12 \mathrm{~h}$ since uplift contain giant particles up to $5 \mathrm{~km}$ altitudes ${ }^{55}$. Vertical velocities were over $\pm 30 \mathrm{cms}^{-1}$ in all cases, and up to $\pm 80 \mathrm{cms}^{-1}$ within the Saharan air layer (SAL), $>200 \mathrm{cms}^{-1}$ within the convective boundary layer, and frequently over $50 \mathrm{cms}^{-1}$ up to $5 \mathrm{~km}$ altitude. High levels of atmospheric turbulence could, therefore, sustain transport of dust particles for longer than expected by gravitational sedimentation. Another mechanism could be solar absorption by the dust particles, possibly generating convection and daytime vertical mixing within the SAL ${ }^{56}$. Darker particles in the solar spectrum could increase convection and mixing. Optical properties of Icelandic volcanic dust are similar to black carbon with a spectral reflectance of a nearly black body $(0.03)^{7,8}$.

The dust source of the storm on $7^{\text {th }}$ November 2013 was Hagavatn dust hot spot, about $70 \mathrm{~km}$ NE of Reykjavik on the southern edge of the glacier Langjokull ${ }^{17}$. HYSPLIT back trajectory at $900 \mathrm{~m}$ calculated moving air parcels from the dust source ${ }^{57}$. The trajectory at $6000 \mathrm{~m}$ could explain the small layer of dust detected by LOAC at this altitude. Air parcels travelled around Iceland for about 144 hours, originating from an altitude of about $1000 \mathrm{~m}$ at the time when dust plumes were visible on satellite images ( $2^{\text {nd }}$ and $1^{\text {st }}$ November 2013). This could indicate that the origin of the thin layer at $6 \mathrm{~km}$ could also have been Icelandic dust. HYSPLIT forward trajectory analysis from $10^{\text {th }}$ January 2016 shows uplift of air parcels from the area of suspended sediments visible on the satellite. The $72 \mathrm{~h}$-trajectories pass the area of Hvalfjordur on $12^{\text {th }}$ January at altitudes above $5 \mathrm{~km}$ and marine areas south of Iceland at altitudes $4-5 \mathrm{~km}$ on $13^{\text {th }}$ January 2016. This could indicate that LOAC captured traces of the jokulhlaup sediments on $12^{\text {th }}$ January 2016, but they were already suspended on $10^{\text {th }}$ January 2016 . It is, however, not clear if this was the material captured by LOAC and CALIPSO at such altitudes. We have not found any evidence that other dust sources were activated during the experiments.

Important sources of additional aeolian material are frequent volcanic eruptions (one eruption each 3-4 years on average) and sediments from glacial outburst floods, so called jokulhlaups, after subglacial eruptions. Jokulhlaups occur in Iceland more frequently than explosive volcanic eruptions ${ }^{58}$. Large jokulhlaups can bring $>5$ million tonnes of very fine deposits (grain size $<0.05 \mathrm{~mm}$ ) available for suspension every year. An example of such large event was Skafta jokulhlaup from September 2015. The sediments were frequently suspended in November and December 2015. Figure 4 reveals that the main dust hot spots were covered with snow while the jokulhlaup sediments were lifted by winds on the south coast of Iceland.

\section{Conclusion}

The Arctic includes important sources of natural dust, which is directly affecting the Arctic atmosphere and cryosphere. Iceland is the largest desert in the Arctic (and Europe), covering $44,000 \mathrm{~km}^{2}$ including the most active dust areas, so called dust hot spots, located in the vicinity of glaciers. This study provides evidence that HLD sources, such as those in Iceland, are actively producing dust aerosols, causing winter Arctic dust storms and impairing air quality, including at high altitudes. Icelandic dust storms can increase particle number concentrations at an altitude of $2 \mathrm{~km}$ to the same values as measured during Saharan dust plumes. Detected volcanic dust particles reworked by glacial processes are, however, smaller in size than crustal dust from the Sahara. Contrarily, atmospheric profiles during clean conditions showed $<5$ particles $\mathrm{cm}^{-3}$ for the particles $>0.2 \mu \mathrm{m}$ in diameter. This is similar to what has been reported from other Arctic locations. More vertical aerosol measurements of HLD storms are needed, although it is a difficult task due to the harsh conditions. Having monitoring and better understanding of dust storms from Iceland (mainly in terms of particle size distributions, concentrations with altitude, transport and deposition) is important for better assessment of the role of volcanic dust in the Arctic climate and cryosphere. HLD does not only cause considerable air pollution close to the surface, it can also significantly influence low-level clouds in the Arctic serving as ice nucleating particles. Dust has been recognized as important climate driver causing snow darkening and melting in Polar Regions in the IPCC report in $2019^{59}$. More research is urgently needed on the HLD sources and impacts on cryosphere and atmosphere.

\section{Methods}

Vertical profile measurements were conducted in south-western Iceland in 2013-2016. Table 1 shows the date, location (Supplementary Fig. S1), altitude range of the flights, altitude of the tropopause, and presence of dust event. It should be noted that the polar vortex was present over Iceland during the January 2016 flights and that the tropopause was not well marked. The number of winter profiles was limited due to loss of most of the instruments during the descending phase in harsh weather. As a result, six flights in winter using weather balloons were successful.

A novel instrument, Light Optical Aerosol Counter (LOAC), was used to measure the aerosols size number distributions and concentrations, to estimate their typology, and to provide the basic meteorological elements up to an altitude of 11.2-32.6 km, depending on the burst altitude of the balloon or telemetry loss (the data are sent in real time). LOAC is an easy-to-launch instrument with the possibility to conduct the flight with ground wind speeds up to $15 \mathrm{~ms}^{-1}$, which is suitable for harsh Icelandic winter conditions. Figure 6 shows an example of LOAC launch from Hvalfjörður on $12^{\text {th }}$ January 2016. This paper focuses on the measurements in the troposphere, although some profiles include stratospheric measurements, and on the different types of aerosols detected with LOAC.

LOAC instrument. Light Optical Aerosol Counter (LOAC) is an aerosol counter/sizer that provides concentration measurements for 19 size classes in the $0.2-100 \mu \mathrm{m}$ size range and an estimate of the typology of the aerosols $s^{60}$. LOAC has been carried on several types of balloons, mainly weather balloons ${ }^{53}$. The weight of the gondola, including the instrument, the alkaline batteries and the telemetry system is about $1 \mathrm{~kg}$. The aerosols are injected into a laser beam using a small pump. The measurements are conducted at two scattering angles: the first angle is at around $12^{\circ}$, where the light scattered by non-spherical particles is dependant strictly on the size of the 


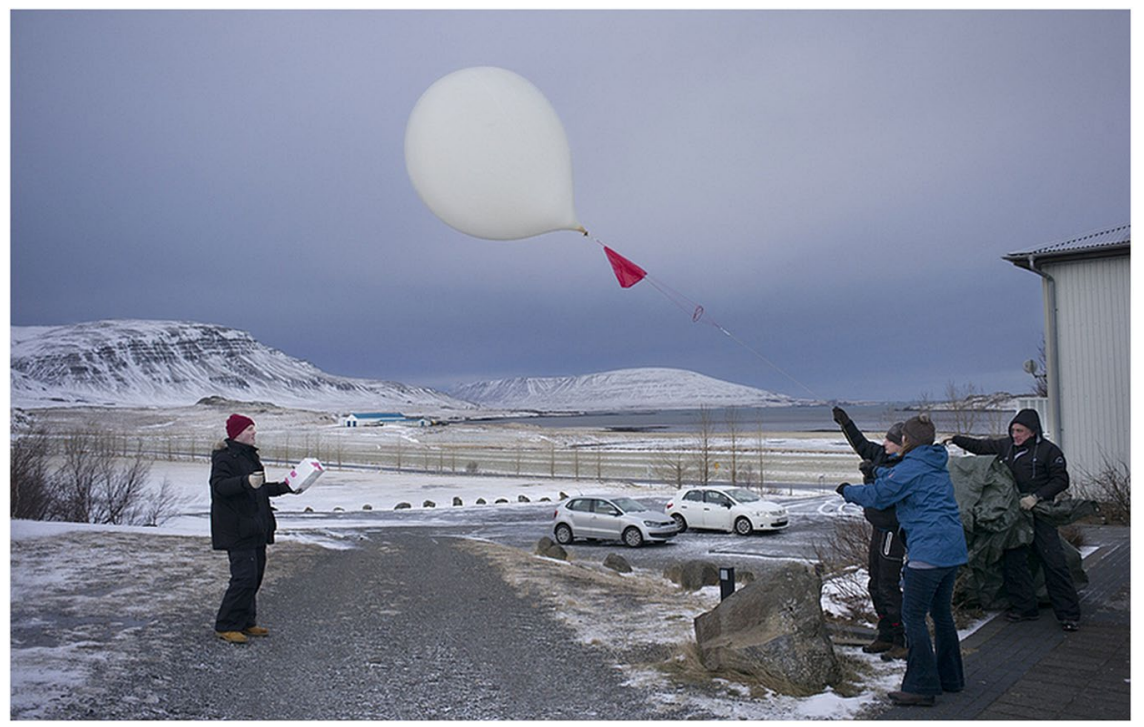

Figure 6. Launch of LOAC during strong winds in Hvalfjordur bay, West Iceland, on $12^{\text {th }}$ January 2016 (Photo by RAX, Ragnar Axelsson).

particles ${ }^{61}$, while the second angle is around $60^{\circ}$, where the scattered light is strongly dependant on the refractive index of the particles $s^{61,62}$. The $12^{\circ}$ angle measurements are used to retrieve the size distribution of the particles, and the combined measured signals at both angles are used to calculate the LOAC "speciation index" for the typology of aerosols. Obtained values of specification index are compared with reference "speciation zones" determined by LOAC in the laboratory for typical samples such as black carbon, liquid droplets, and ice particles. In case of Icelandic volcanic dust, a specific "speciation zone" has been established in the laboratory using different samples of volcanic dust and ash collected in Iceland. The speciation index is calculated for each size class. The typology is determined for six size "super-classes" centred on $0.3 \mu \mathrm{m}, 0.8 \mu \mathrm{m}, 2.5 \mu \mathrm{m}, 8.0 \mu \mathrm{m}, 16.5 \mu \mathrm{m}$, and 30 $\mu \mathrm{m}$ that combine the speciation index of three consecutive size classes. The typology indicates if a specific nature of particles dominates in the sampled air mass; no indication can be retrieved in the case of a heterogeneous medium. The unambiguous presence of dust/ash is stated if "dust/ash" typologies are retrieved for at least three consecutive super-classes.

Concentration measurement uncertainty is of $\pm 20 \%$ for the concentrations higher than 10 particles $\mathrm{cm}^{-3}$. The uncertainty increases to about $\pm 30 \%$ for submicronic particle concentrations higher than 1 particle $\mathrm{cm}^{-3}$, and to about $\pm 60 \%$ for concentrations smaller than $10^{-2}$ particle $\mathrm{cm}^{-3}$. Additional uncertainties come from the size calibration, which are of $\pm 0.025 \mu \mathrm{m}$ for particles smaller than $0.6 \mu \mathrm{m}, 5 \%$ for particles in the $0.7-2 \mu \mathrm{m}$ range, and of $10 \%$ for particles greater than $2 \mu \mathrm{m}$. Accurate detection of submicronic particles and larger particles by LOAC was validated during numerous inter-comparison sessions with different instruments ${ }^{42,59,60}$. LOAC performs measurements every 10 seconds, typically over a session of 10 or 15 minute, while a one-minute automatic self-calibration is performed to control electronic noise and to correct the effect of temperature variation on the electronics in-between the periods. Detailed information on LOAC can be found in Renard et al. ${ }^{60}$.

Balloon-borne dust measurements. Six vertical high-altitude profiles obtained with LOAC at 19 particle size classes are presented in Fig. 7. The peaks in the aerosol concentrations with the altitude can be related to different types of aerosol such as marine aerosols, clouds, pollution particles, or ice (Fig. 1). Clouds of liquid droplets and/or ice particles are characterized by the presence of larges particles $(>10 \mu \mathrm{m})$, as shown in green, yellow, and red in Fig. 7, for example, for the flight on $12^{\text {th }}$ January 2016. Micron and submicron liquid aerosols are present from the ground to the stratosphere (Figs 1,7 ).

Meteorological conditions during the flights. Five of six conducted flights (Table 1) occurred during dust events from different dust sources in Iceland as described in Arnalds et al. ${ }^{17}$ (Supplementary Fig. S1). Meteorological conditions controlled the main characteristics of single dust events. Event 1 ( $7^{\text {th }}$ November 2013) was a small dust storm with surface winds of about $8 \mathrm{~ms}^{-1}$, precipitation of $1.5 \mathrm{~mm}$, and a surface temperature of about $3^{\circ} \mathrm{C}$. Events 2,3 and 4 (on $9^{\text {th }}, 10^{\text {th }}$, and $12^{\text {th }}$ January 2016) were moderate-severe dust storms with surface winds of about $15 \mathrm{~ms}^{-1}$ (Supplementary Fig. S2) and surface temperatures from $0{ }^{\circ} \mathrm{C}$ to $-5^{\circ} \mathrm{C}$. The dust event on $13^{\text {th }}$ January 2016 was not captured by LOAC. There was no dust present in the atmosphere in Iceland on $28^{\text {th }}$ January 2015.

Cloud-Aerosol lidar and infrared pathfinder satellite observations (CALIPSO). Detection of aerosols in high latitude regions such as Iceland is complicated for most of the satellite-based passive remote sensing instruments due to frequent cloud cover, darkness in winter, and bright surfaces. To be able to compare results from LOAC we used data from Cloud-Aerosol Lidar and Infrared Pathfinder Satellite Observations (CALIPSO) 

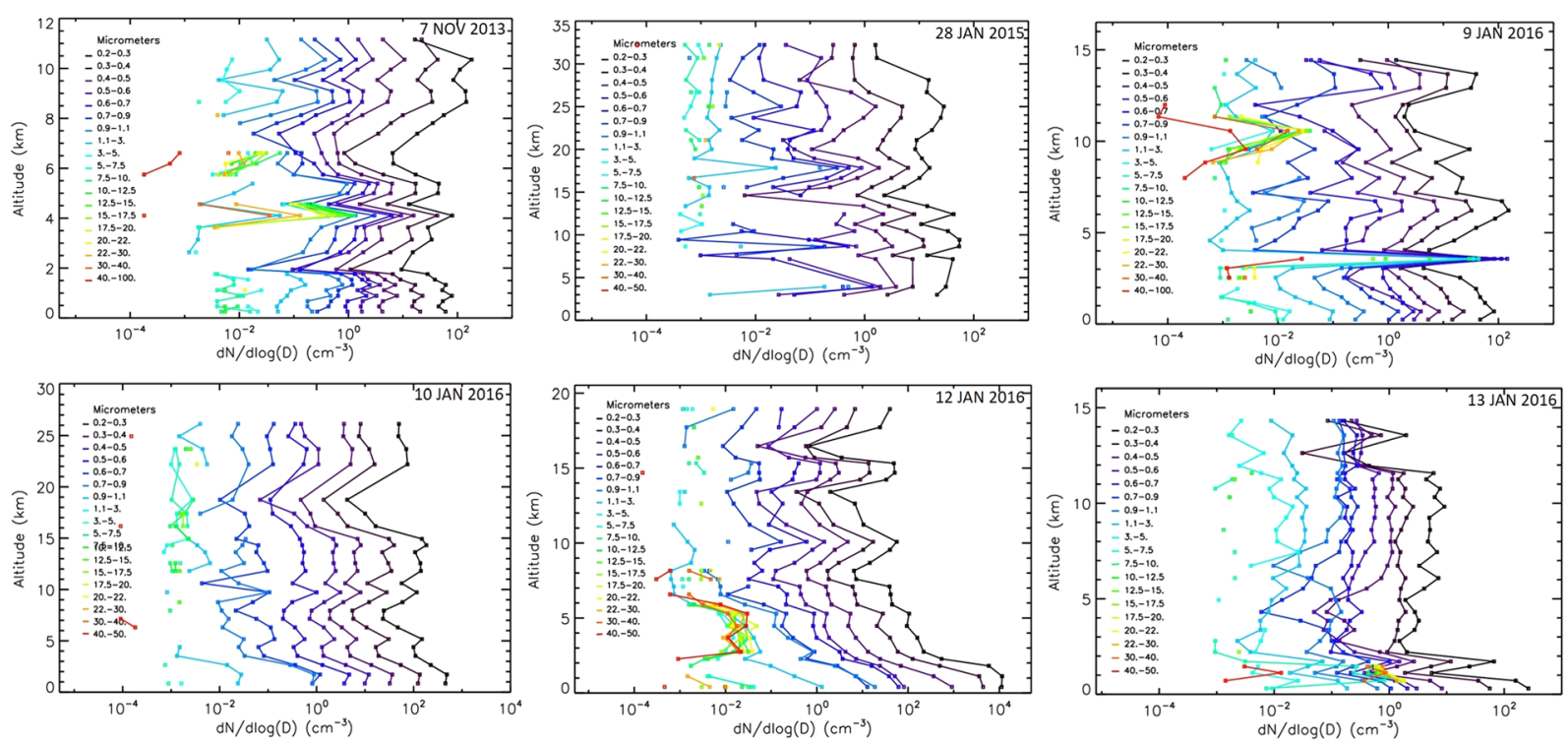

Figure 7. Particle size distributions at different altitudes for the flights on 7 th November $2013,28^{\text {th }}$ January $2015,9^{\text {th }}$ January $2016,10^{\text {th }}$ January $2016,12^{\text {th }}$ January 2016 , and $13^{\text {th }}$ January 2016.

around Iceland. CALIPSO can detect aerosols in clear sky conditions, beneath thin cloud layers, as well as at night, and it provides high altitude vertical profiles of atmospheric aerosol distributions ${ }^{63}$. The CALIPSO satellite carries the Cloud-Aerosol Lidar with Orthogonal Polarization (CALIOP) instrument that operates at two wavelengths $(532 \mathrm{~nm}$ and $1064 \mathrm{~nm})$ and it provides continuous observation with attenuated backscatter covering the entire globe. The vertical distribution of different types of aerosols from LOAC flights is compared to CALIPSO cross sections of $532 \mathrm{~nm}$ total attenuated backscatter and the vertical feature mask for the overpass around Iceland. Data were obtained from the NASA Langley Research Center Atmospheric Science Data Center (http://wwwcalipso.larc.nasa.gov/products/lidar/browse_images/show_calendar.php). Comparisons of CALIPSO products with different aerosol observation networks have shown good agreement, but the CALIPSO retrievals may lead to an underestimation of dust optical depths ${ }^{54,64}$.

\section{Data availability}

The LOAC data that support the findings of this study are available at the ESPRI Data Centre of the French Atmosphere Infrastructure (AERIS, http://cds-espri.ipsl.fr/etherTypo/index.php?id=1699\&L=1). National Aeronautics and Space Administration (NASA) supports an open data policy and encourage publication of imagery from Worldview as used in Fig. 4 (https://worldview.earthdata.nasa.gov) as well as from CALIPSO as used in Fig. 5 (https://www-calipso.larc.nasa.gov).

Received: 21 May 2019; Accepted: 7 October 2019;

Published online: 06 November 2019

\section{References}

1. Bond, T. C. et al. Bounding the role of black carbon in the climate system: a scientific assessment. J. Geophys. Res. Atmos. 118, 5380-5552 (2013).

2. Najafi, M. R., Zwiers, F. W. \& Gillett, N. P. Attribution of Arctic temperature change to greenhouse-gas and aerosol influences. Nat. Clim. Change 5, 246-249 (2015)

3. Sand, M. et al. Aerosols at the Poles: An AeroCom Phase II multi-model evaluation. Atmos. Chem. Phys. 17, 12197-12218 (2017).

4. Boy, M. et al. Interactions between the atmosphere, cryosphere and ecosystems at northern high latitudes. Atmos. Chem. Phys. 19, 2015-2061 (2019).

5. Goldenson, N. et al. Arctic climate response to forcing from light-absorbing particles in snow and sea ice in CESM. Atmos. Chem. Phys. 12, 7903-7920 (2012).

6. Painter, T. H., Skiles, S. M., Deems, J. S., Bryant, A. C. \& Landry, C. C. Dust radiative forcing in snow of the Upper Colorado River Basin: A 6 year record of energy balance, radiation, and dust concentrations. Water Resour Res. 48, 1-14 (2012).

7. Peltoniemi, J. I. et al. Soot on snow experiment: bidirectional reflectance factor measurements of contaminated snow. Cryosphere 9 , $1-15$ (2015).

8. Meinander, O. et al. Brief Communication: Light-absorbing impurities can reduce the density of melting snow. Cryosphere 8 , 991-995 (2014).

9. Meinander, O., Dagsson-Waldhauserova, P. \& Arnalds, O. Icelandic volcanic dust can have a significant influence on the cryosphere in Greenland and elsewhere. Polar Res 35, 1-2 (2016).

10. Wittmann, M. et al. Impact of dust deposition on the albedo of Vatnajökull ice cap, Iceland. Cryosphere 11, 741-754 (2017).

11. Di Mauro, B. et al. Saharan dust events in the European Alps: role on snowmelt and geochemical characterization. Cryosphere 13, $1147-1165$ (2019).

12. Kylling, A., Groot Zwaaftink, C. D. \& Stohl, A. Mineral dust instantaneous radiative forcing in the Arctic. Geophys. Res. Lett. 45, 4290-4298 (2018). 
13. Croft, B. et al. Processes controlling the annual cycle of Arctic aerosol number and size distributions. Atmos. Chem. Phys. 16, 3665-3682 (2016).

14. Bullard, J. E. et al. High Latitude Dust in the Earth System. Rev. Geophys. 54, 447-485 (2016)

15. Groot Zwaaftink, C. D., Grythe, H., Skov, H. \& Stohl, A. Substantial contribution of northern high-latitude sources to mineral dust in the Arctic. J. Geophys. Res. Atmos. 121, 13678-13697 (2016).

16. Dagsson-Waldhauserova, P., Arnalds, O. \& Olafsson, H. Long-term variability of dust events in Iceland. Atmos. Chem. Phys. 14, 13411-13422 (2014).

17. Arnalds, O., Dagsson-Waldhauserova, P. \& Olafsson, H. The Icelandic volcanic Aeolian environment: Processes and impacts - A review. Aeolian Res 20, 176-195 (2016).

18. Butwin, M. K., von Löwis, S. \& Pfeffer, M. \& Thorsteinsson, Th. The Effects of Volcanic Eruptions on the Frequency of Particulate Matter Suspension Events in Iceland. J. Aerosol Sci. 128, 99-113 (2019).

19. Nakashima, M. \& Dagsson-Waldhauserová, P. A 60 Year Examination of Dust Day Activity and Its Contributing Factors From Ten Icelandic Weather Stations From 1950 to 2009. Front. Earth Sci. 6, 245-253 (2019).

20. Arnalds, O. Dust sources and deposition of aeolian materials in Iceland. Icelandic Agric. Sci. 23, 3-21 (2010).

21. Baddock, M., Mockford, T. \& Bullard, J. E. \& Thorsteinsson, Th. Pathways of high-latitude dust in the North Atlantic. Earth Planet Sci Lett. 459, 170-182 (2017).

22. Beckett, F., Kylling, A., Sigurðardóttir, G., von Löwis, S. \& Witham, C. Quantifying the mass loading of particles in an ash cloud remobilized from tephra deposits on Iceland. Atmos. Chem. Phys. 17, 4401-4418 (2017).

23. Groot Zwaaftink, C. D. et al. Temporal and spatial variability of Icelandic dust emissions and atmospheric transport. Atmos. Chem. Phys. 17, 10865-10878 (2017).

24. Moroni, B. et al. Mineralogical and chemical records of Icelandic dust sources upon Ny-Ålesund (Svalbard Islands). Front. Earth Sci. 6, 187-219 (2018).

25. Arnalds, O., Olafsson, H. \& Dagsson-Waldhauserova, P. Quantification of iron-rich volcanogenic dust emissions and deposition over the ocean from Icelandic dust sources. Biogeosciences 11, 6623-6632 (2014).

26. Dagsson-Waldhauserova, P. et al. Physical properties of suspended dust during moist and low wind conditions in Iceland. Icelandic Agric. Sci. 27, 25-39 (2014).

27. Dagsson-Waldhauserova, P. et al. Snow-dust storm: A case study from Iceland, March $7^{\text {th }}$ 2013. Aeolian Res. 16, 69-74 (2015).

28. Dagsson-Waldhauserova, P., Magnusdottir, A. Ö., Olafsson, H. \& Arnalds, O. The spatial variation of dust particulate matter concentrations during two Icelandic dust storms in 2015. Atmosphere 7, 77 (2016).

29. Blechschmidt, A.-M., Kristjansson, J. E., Olafsson, H., Burkhart, J. F. \& Hodnebrog, Ø. Aircraft-based observations and highresolution simulations of an Icelandic dust storm. Atmos. Chem. Phys. 12, 7949-7984 (2012).

30. Arnalds, O., Thorarinsdottir, E. F., Thorsson, J., Dagsson-Waldhauserova, P. \& Agustsdottir, A. M. An extreme wind erosion event of the fresh Eyjafjallajokull 2010 volcanic ash. Sci. Rep 3, 1257 (2013).

31. Liu, E. J. et al. Ash mists and brown snow: Remobilization of volcanic ash from recent Icelandic eruptions. J. Geophys. Res. Atmos. 119, 9463-9480 (2014)

32. Laakso, L. et al. In Nucleation and Atmospheric Aerosols: Hot-air Balloon Measurements of Vertical Variation of Boundary Layer New Particle Formation. 698-701 (Springer, Dordrecht, 2007).

33. Bates, T. S. et al. Measurements of atmospheric aerosol vertical distributions above Svalbard, Norway, using unmanned aerial systems (UAS). Atmos. Meas. Tech. 6, 2115-2120 (2013).

34. Moroni, B. et al. Vertical Profiles and Chemical Properties of Aerosol Particles upon Ny-Ålesund (Svalbard Islands). Adv. Meteorol. 2015(292081), 1-11 (2015)

35. Ferrero, L. et al. Vertical profiles of aerosol and black carbon in the Arctic: a seasonal phenomenology along 2 years (2011-2012) of field campaigns. Atmos. Chem. Phys. 16, 12601-12629 (2016).

36. Weigel, R. et al. Enhancements of the refractory submicron aerosol fraction in the Arctic polar vortex: feature or exception? Atmos. Chem. Phys. 14, 12319-12342 (2014).

37. Pitts, M. C., Poole, L. R., Dörnbrack, A. \& Thomason, L. W. The 2009-2010 Arctic polar stratospheric cloud season: a CALIPSO perspective. Atmos. Chem. Phys. 11, 2161-2177 (2011).

38. Di Pierro, M., Jaeglé, L., Eloranta, E. W. \& Sharma, S. Spatial and seasonal distribution of Arctic aerosols observed by the CALIOP satellite instrument (2006-2012). Atmos. Chem. Phys. 13, 7075-7095 (2013).

39. Weinzierl, B. et al. Airborne measurements of dust layer properties, particle size distribution and mixing state of Saharan dust during SAMUM 2006. Tellus 61B, 96-117 (2009).

40. van der Does, M., Knippertz, P., Zschenderlein, P., Giles Harrison, R. \& Stuut, J.-B. W. The mysterious long-range transport of giant mineral dust particles. Sci Adv. 4, 1-8 (2018).

41. Marenco, F. et al. Unexpected vertical structure of the Saharan Air Layer and giant dust particles during AER-D. Atmos. Chem. Phys. 18, 17655-17668 (2018)

42. Renard, J.-B. et al. In situ measurements of desert dust particles above the western Mediterranean Sea with the balloon-borne Light Optical Aerosol Counter/sizer (LOAC) during the ChArMEx campaign of summer 2013. Atmos. Chem. Phys. 18, 3677-3699 (2018).

43. Ryder, C. L. et al. Coarse-mode mineral dust size distributions, composition and optical properties from AER-D aircraft measurements over the tropical eastern Atlantic. Atmos. Chem. Phys. 18, 17225-17257 (2018).

44. Jégou, F. et al. Stratospheric aerosols from the Sarychev volcano eruption in the 2009 Arctic summer. Atmos. Chem. Phys. 13, 6533-6552 (2013).

45. The Environment Agency of Iceland. Ambient Air Quality (2019). Available at, https://www.loftgaedi is (Accessed: 6th May 2019).

46. The Icelandic Meteorological Office. Harmonie: Snow Water Equivalent (2019). Available at, http://brunnur.vedur.is/kort/ harmonie/2016/01/10/06/harmonie_island_sd.html (Accessed: 6th May 2019).

47. Sanchez-Marroquin, A. et al. Characterisation of the filter inlet system on the BAE-146 research aircraft and its use for size resolved aerosol composition measurements. Atmos. Meas. Tech. Discuss. 12, 196, in review (2019).

48. Vignelles, D. et al. Balloon-borne measurement of the aerosol size distribution from an Icelandic flood basalt eruption. Earth Planet Sci Lett. 53, 252-259 (2016)

49. Möller, R. et al. Persistent albedo reduction on southern Icelandic glaciers due to ashfall from the 2010 Eyjafjallajökull eruption. Remote Sens. Environ. 233, 111396 (2019).

50. Kupiszewski, P. et al. Vertical profiling of aerosol particles and trace gases over the central Arctic Ocean during summer. Atmos. Chem. Phys. 13, 12405-12431 (2013).

51. Mogo, S. et al. In situ measurements of aerosol optical properties and number size distributions in a coastal region of Norway during the summer of 2008. Atmos. Chem. Phys. 12, 5841-5857 (2012).

52. Tunved, P., Ström, J. \& Krejci, R. Arctic aerosol life cycle: linking aerosol size distributions observed between 2000 and 2010 with air mass transport and precipitation at Zeppelin station, Ny-Ålesund, Svalbard. Atmos. Chem. Phys. 13, 3643-3660 (2013).

53. Renard, J.-B. et al. LOAC: a small aerosol optical counter/sizer for ground-based and balloon measurements of the size distribution and nature of atmospheric particles - Part 2: First results from balloon and unmanned aerial vehicle flights. Atmos. Meas. Tech. 9, 3673-3686 (2016).

54. Pappalardo, G. et al. EARLINET correlative measurements for CALIPSO: first intercomparison results. J. Geophys. Res. 115, D00H19 (2010). 
55. Ryder, C.L. et al. Coarse and Giant Particles are Ubiquitous in Saharan Dust Export Regions and are Radiatively Significant over the Sahara. Atmos. Chem. Phys. Discuss. 421, in review (2019).

56. Gasteiger, J. et al. Particle settling and vertical mixing in the Saharan Air Layer as seen from an integrated model, lidar, and in situ perspective. Atmos. Chem. Phys. 17, 297-311 (2017).

57. Draxler, R. R. \& Rolph, G. D. HYSPLIT (HYbrid Single-Particle Lagrangian Integrated Trajectory) Model access via NOAA ARL READY Website at, http://ready.arl.noaa.gov/HYSPLIT.php (Accessed: 6th May 2019, NOAA Air Resources Laboratory, Silver Spring, MD, 2015).

58. Jensen, E. H. et al. Hættumat vegna jökulhlaupa í Skaftá [Danger of Skafta jokulhlaup]. Icelandic Meteorological Office Report VÍ 2018-0xx (2018). Available at, http://www.vedur.is/media/Eplican\%C3\%A1mskei\%C3\%B0/2018_skaftarhlaup_soguleg_gogn_ lokadrog_rs.pdf (Accessed: $6^{\text {th }}$ May 2019).

59. IPCC, 2019. Summary for Policymakers. In: IPCC Special Report on the Ocean and Cryosphere in a Changing Climate [H.-O. Pörtner, D. C. Roberts, V. Masson-Delmotte, P. Zhai, M. Tignor, E. Poloczanska, K. Mintenbeck, M. Nicolai, A. Okem, J. Petzold, B. Rama, N. Weyer (eds)]. In press.

60. Renard, J.-B. et al. LOAC: a small aerosol optical counter/sizer for ground-based and balloon measurements of the size distribution and nature of atmospheric particles - Part 1: Principle of measurements and instrument evaluation. Atmos. Meas. Tech. 9, 1721-1742 (2016).

61. Lurton, T. et al. Light scattering at small angles by atmospheric irregular particles: modelling and laboratory measurements. Atmos., Meas. Tech. 7, 931-939 (2014).

62. Renard, J.-B. et al. Scattering properties of sand. 2. Results for sands from different origins. Appl. Opt. 49, 3552-3559 (2010).

63. Winker, D. M. et al. Overview of the CALIPSO mission and CALIOP data processing algorithms. J. Atmos. Oceanic Technol. 26, 2310-2323 (2009).

64. Kittaka, C., Winker, D. M., Vaughan, M. A., Omar, A. \& Remer, L. A. Intercomparison of column aerosol optical depths from CALIPSO and MODIS-Aqua. Atmos. Meas. Tech. 4, 131-141 (2011).

\section{Acknowledgements}

The instrument and the gondola were built by ENVEA and MeteoModem companies. The flights were conducted in cooperation with the Icelandic Meteorological Office and the Agricultural University of Iceland. The various copies of LOAC used in the campaigns were funded by the French program "VOLTAIRE Labex (Laboratoire d'Excellence ANR-10-LABX-100-01)". The preparation of this manuscript was funded by the Icelandic Research Fund (Rannis) Grant No. 152248-051. We acknowledge the use of imagery from the NASA Worldview application (https://worldview.earthdata.nasa.gov), part of the NASA Earth Observing System Data and Information System (EOSDIS), as well as NASA CALIPSO application (Dr. Charles Trepte, Cloud-Aerosol Lidar and Infrared Pathfinder Satellite Observations, https://www-calipso.larc.nasa.gov). We thank Mark Francis Sixsmith for his proofreading of this work. RAX (photographer Ragnar Axelsson) captured our field work in the greatest detail and we are thankful to use his photograph in this manuscript.

\section{Author contributions}

P.D.-W. coordinated the writing of the paper. J.-B.R. made original plans for the project. P.D.-W., J.-B.R., H.O., D.V., N.V. and V.D. took part in data collection and analyses. G.B. commented and discussed the results during the writing.

\section{Competing interests}

The authors declare no competing interests.

\section{Additional information}

Supplementary information is available for this paper at https://doi.org/10.1038/s41598-019-51764-y.

Correspondence and requests for materials should be addressed to P.D.

Reprints and permissions information is available at www.nature.com/reprints.

Publisher's note Springer Nature remains neutral with regard to jurisdictional claims in published maps and institutional affiliations.

Open Access This article is licensed under a Creative Commons Attribution 4.0 International License, which permits use, sharing, adaptation, distribution and reproduction in any medium or format, as long as you give appropriate credit to the original author(s) and the source, provide a link to the Creative Commons license, and indicate if changes were made. The images or other third party material in this article are included in the article's Creative Commons license, unless indicated otherwise in a credit line to the material. If material is not included in the article's Creative Commons license and your intended use is not permitted by statutory regulation or exceeds the permitted use, you will need to obtain permission directly from the copyright holder. To view a copy of this license, visit http://creativecommons.org/licenses/by/4.0/.

(C) The Author(s) 2019 